\title{
Altar Call of Cthulhu: Religion and Millennialism in H.P. Lovecraft's Cthulhu Mythos
}

\author{
Benjamin E. Zeller D \\ Department of Religion, Lake Forest College, Lake Forest, IL 60045, USA; zeller@lakeforest.edu
}

Received: 11 October 2019; Accepted: 23 December 2019; Published: 30 December 2019

\begin{abstract}
Religion suffuses H.P. Lovecraft's (1890-1937) short stories-the most famous of which, "The Call of Cthulhu," has led to a literary subculture and a shared mythos employed by Lovecraft's successors. Despite this presence of religion in Lovecraft's work, scholars of religion have paid relatively little attention to Lovecraft and the Cthulhu mythos, with a few notable exceptions. This article offers a close analysis of millennialism within Lovecraft's thought, especially as expressed in three of his "Cthulhu mythos" stories: "The Call of Cthulhu," "The Dunwich Horror," and "The Shadow over Innsmouth." This article considers Lovecraft's formative experiences and non-fiction writings so as to contextualize his approach and millennial outlook. Tied to his nativist views of social decline, I argue that Lovecraft expresses in his fiction a peculiar form of millennialism, "anti-millennialism," which entails the reversal of traditional millennialism, offering no hope in a collective salvation, but rather expectation that the imminent future would bring only decline.
\end{abstract}

Keywords: H.P. Lovecraft; millennialism; declension; nativism; Cthulhu mythos; weird fiction; horror; religion and literature; religion and science fiction

\section{Introduction}

Religion suffuses H.P. Lovecraft's (1890-1937) short stories-the most famous of which, "The Call of Cthulhu," has led to a literary subculture and a shared mythos employed by Lovecraft's successors. His work features malevolent supernatural entities that the author and his imitators variously refer to as Old Ones, Elder Gods, Outer Ones, or simply gods. Lovecraft's stories involve demonic beings, "blasphemous cults," and mysterious sacred texts held by orders of priests and priestesses. Perhaps most famously, his signature short story, "The Call of Cthulhu," centers on the ancient god Cthulhu, his human worshippers, and those who become enmeshed in the mystery of this "dead, yet dreaming" god's fate. This pattern of engagement with religious topics repeats throughout Lovecraft's corpus, especially the several dozen short stories that have come to be called the "Cthulhu mythos," since they share much of the same cosmology and narrative world as "The Call of Cthulhu." Lovecraft's literary successors, led by August Derleth, who co-founded Arkham House Publishers to promulgate Lovecraft's work, expanded this rich religious vision to an even greater extent, as did later authors (Mackley 2013). By some recent counts, nearly one hundred published authors have adopted the "Cthulhu mythos" and written stories set in Lovecraft's world-many of which share this same cluster of themes of gods, demons, cults, and sacred texts (Jarocha-Ernst 1999).

Despite this presence of religion in Lovecraft's work, scholars of religion have paid relatively little attention to Lovecraft and the Cthulhu mythos, with a few notable exceptions. Only a handful of panels at major religious studies conferences (American Academy of Religion, International Association for the History of Religions, etc.) in recent decades have included coverage of Lovecraft, and only four articles on Lovecraft and his works appears in the ATLA publication database, which is the standard catalog for religious studies. The few religious studies scholars who have studied Lovecraft have focused on unpacking his connections to Western Esotericism, especially his impact on Esotericists 
whose religious practices have been inspired by Lovecraft's writings (Engle 2014; Hanegraaff 2007; Bolton 2011; Davis 2014), or his influence on other new religions (Colavito 2005, pp. 307-40). Such scholars have demonstrated Lovecraft's enduring impact within that religious milieu. Other scholars have traced connections between Lovecraft's work and a variety of new religious movements, often those upholding visions of alternative archaeologies or histories (Caterine 2014; Card 2019). Folklorists, mythologists, and English literary scholars have focused far more attention on Lovecraft and his corpus, with a dozen books, numerous articles, and for a time even a yearly journal, Lovecraft Studies, on H.P. Lovecraft's work. "From an academic point of view, Lovecraft has ceased to be an author beyond the pale of canonization, or even one on the verge of canonization; he is an author who has arrived," explains literary studies scholar Hantke (2013, p. 137) in his study of Lovecraft's inclusion within the canon of American literature. Literature specialists now turn to Lovecraft with increasing frequency, as demonstrated by two recent anthologies dedicated to Lovecraft's texts, antecedents, influences, and legacies (Sederholm and Weinstock 2016; Moreland 2018a; see also Simmons 2013a).

Yet few of those scholars pay much attention to religion. This is despite the fact that the Cthulhu stories are fundamentally about gods, demons, religious groups, and apocalyptic expectations. No doubt Lovecraft's position as an avowed atheist and his clear espousal of materialist philosophy led to this inattention by religious studies scholars, and a secondary place of consideration for religion among dedicated Lovecraft scholars from other fields. Further complicating examinations of religion within Lovecraft's oeuvre, the author's materialism suffused his treatment of such gods, demons, and other brings, blending elements of the natural and supernatural within his fiction. Delineating what counts as 'religion' within Lovecraft's thought is therefore not a simple task. While attention to Lovecraft's philosophical foundations has become a staple in Lovecraft scholarship (Harman 2012; Carlin and Allen 2013; Moreland 2018b), scholars tend to avoid associating the author's deeply pessimistic millennial outlook with religion. Analyzing Lovecraft's life and literature through the lens of religious studies offers the opportunity to understand the author's work as part of a millennial tradition that, although presented through fiction and in a materialist frame, reflects deep religious impulses. I argue that religious thought occupies an important role in Lovecraft's thought and fiction, specifically the concept of millennialism. This article offers a close analysis of Lovecraft's millennialism, especially as expressed in three of his "Cthulhu mythos" stories.

\section{Lovecraft's Background}

Science fiction author and critic Paul J. Nahim has characterized the science fiction genre as offering creators and readers the opportunity to unshackle constraints on the imagination and engage in acts of metaphysical speculation (Nahim 2014, p. 10). For Lovecraft, such speculation emerges from his formative life experiences, influences, and philosophies. Most studies of Lovecraft root his formative imaginative world as firmly materialist. "The metaphysical background of Lovecraft's stories is a 'cosmic indifferentism' rooted in the nihilistic and atheist materialism that Lovecraft professed," argues Erik Davis, in his study of Lovecraft within the occult milieu (Davis 2014, p. 492). Scholar of esotericism Wouter Hanegraaff concurred, "Contrary to many of his admirers, Lovecraft was a radical materialist who saw all religions (including esotericism or occultism of any variety) as self-evident delusions. He does not ever seem to have been tempted to embrace any kind of religious or spiritual belief." (Hanegraaff 2007, p. 90). Yet despite Lovecraft's avowed atheism, materialistic philosophy, and dismissal of religion, an examination of his biography as detailed in his own writing shows a deep resonance of religious thought, a persistent presence of a sense of awe which at times became dread, but which reveals an enduring religious influence.

H.P. Lovecraft was born 20 August 1890, in Providence, Rhode Island. As a matter of pride, Lovecraft traced his ancestry back to early Puritan New England settlers, "old-fashioned gentlefolk which meant considerable in the old aristocratic Providence East Side neighborhood" in which Lovecraft lived, in the words of a contemporary associate of the author (Camp 1975, p. 10). Biographer L. Sprague de Camp, whose detailed study serves as the foundation for later Lovecraft scholarship, was unable to 
verify Lovecraft's own statements, tracing the family only back to early nineteenth-century Connecticut farmers, rather than the titled British peers that Lovecraft claimed (Camp 1975, p. 10). Both his parents suffered from mental illness and were hospitalized for what at the time was characterized as madness. His father died of what appeared to be complications from syphilis when the younger Lovecraft was nine years old, after having been intermittingly committed to Rhode Island's Butler Hospital for the Insane for the previous six years owing to a series of hallucinations and fits of anger (Klinger 2014, p. 33; Camp 1975, p. 16). His mother Sarah suffered a nervous breakdown in 1919, was also hospitalized at Butler, and remained there until she died three years later after a failed gallbladder operation (Klinger 2014, p. 24; Camp 1975, p. 134). With both parents having been confined to and eventually dying in a mental institution, H.P. Lovecraft was therefore no stranger to madness or death. Although de Camp argues that the younger Lovecraft knew little of his father's medical condition owing to his young age at the time, and that the death of this distant "shadowy figure" had little impact on the child (Camp 1975, pp. 16, 29), the same cannot be said of his mother's decline and death. De Camp explains that Lovecraft was deeply affected by his mother's decline, suffering a nervous breakdown of his own during her hospitalization due to his empathetic response (Camp 1975, p. 134). After her death, Lovecraft lamented that "much of my former interest in things lay in discussing them with my mother," and he longed to "find oblivion" rather than face "so dismal a farce" as life without her (Lovecraft to Kleiner, 12 June 1921, in Lovecraft 1965a, p. 139).

During her life, Sarah Lovecraft introduced a genteel New England Protestantism to the young Howard. The younger Lovecraft would have little of organized religion, writing in his reminiscences that he was "so pestiferous an iconoclast" that he was dismissed from Sunday school at the age of twelve $^{1}$ (in Joshi 2010a, p. 2). Of Christianity, Lovecraft wrote to his friend and fellow author Rheinhart Kleiner that it offended his rationalist and materialist philosophical perspectives, that his "close reasoning" offended the "pious mossbacks," who were "hopelessly bound to unfounded dogmata and traditions" (Lovecraft to Kleiner, 7 March 1920, in Lovecraft 1965a, p. 110). Based on his own telling, Lovecraft's apparent rationalism led him to become a materialist and iconoclast even from a young age. While one must take cautiously Lovecraft's account of his childhood religiosity-the cited material was composed by Lovecraft in a letter at the age of thirty-it reveals at the very least how Lovecraft remembered and framed his childhood religious experiences. Novelist and essayist Michel Houellebecq frames it slightly differently, and through a psychological rather than philosophical lens. Alluding to Lovecraft's difficult childhood and lack of close friends, he explains that "he lost his childhood; he also lost his faith. The world sickened him and he saw no reason to believe that by looking at things better they might appear different. He saw religions as so many sugar-coated illusions made obsolete by the progress of science" (Houellebecq 2005, p. 31). Regardless of whether psychological turmoil or philosophical speculation led him to materialism, Lovecraft eventually came to reject religion and embrace such a position.

In 1922, shortly before his mother died, Lovecraft penned a treatise titled "Confessions of Unfaith" to be published in his friend Paul J. Campbell's short-lived freethinkers' amateur magazine, Liberal. In this confession, Lovecraft positioned himself as a "skeptic and analyst" in terms of all religious claims. Yet he also declared himself a proponent of determinism and fatalism, as well as a pessimist on all questions of meaning and the ultimate fate of humanity (reprinted in Joshi 2010a, p. 2). ${ }^{2} \mathrm{He}$ invoked Friedrich Nietzsche and the failure of the previous year's Paris Peace Conference as helping him "perfect" his cynicism (Joshi 2010a, p. 6). Lovecraft also credits his discovery of science, and his

1 Lovecraft was unclear about the age of his dismissal from Sunday School, writing variously that it happened at age five and age twelve. Joshi (2001, p. 23) considers twelve most likely, given Lovecraft's other statements on his "philosophical development."

2 While one can access the manuscript copy of "Confession of Unbelief" in the Brown University Library H.P. Lovecraft Collection, I use a reprint edition. H.P. Lovecraft, "A Confession of Unfaith," in S.T. Joshi's Against Religion: The Atheist Writings of H.P. Lovecraft (Joshi 2010a). Lovecraft also copied much of the Confession verbatim in a letter sent to Edwin Baird, 3 February 1924, in Lovecraft 1965, pp. 295-304. 
time as an amateur "scientific student" pouring through a "new stock of simple scientific text-books" (Joshi 2010a, p. 4) as leading to his embracing of a mechanistic worldview. Yet he identifies two moments as the "most poignant sensations of my existence" - the first his discovery of Hellenistic paganism (discussed below), and the second his encounter of the scientific model of "myriad suns and worlds of infinite space" that demonstrated to him the "cosmic futility" of human existence (Joshi 2010a, p. 5). The latter experience-that of recognizing the insignificant place of humanity in the scale of the cosmos-he credits as serving as a foundation for his ethic of cynicism. Reading the document as a whole, Lovecraft situates himself as agnostic, nihilistic, and bound to a vision of objective science that reveals the lack of inherent meaning within human existence.

Yet the Confession also points another direction. Though a cynic and materialist, the young H.P. Lovecraft was not irreligious, or at least not immune from the characteristic sentiments of religion. Deeply thoughtful and at the same time immersed in the world around him, he found himself profoundly affected by overwhelming feelings that Rudolph Otto would call the numinous. Lovecraft writes of a formative childhood memory overlooking the city of Providence, Rhode Island: "I can see myself as a child ... on the railway bridge ... looking across and downward at the business part of the town, and feeling the imminence of some wonder which I could neither describe nor fully conceive - and there has never been a subsequent hour of my life when kindred sensations have been absent" (Lovecraft to Derleth January 1930, in Lovecraft 1965b, p. 100). That Lovecraft admits to a lifelong and permanent feeling of "imminence" and "wonder" is noteworthy, given the darkness of his fiction. Even Houellebecq admits that Lovecraft confessed to recognizing the attraction of an "enchanted circle of religious belief," but one "from which he felt banished" (Houellebecq 2005, p. 31). While not religious, Lovecraft never quite left the shadow of religion.

This sense of imminent wonder, of the presence of some overpowering presence-the mysterium tremendum, to use Rudolf Otto's language (Otto 1917)—planted a seed that would later bloom in Lovecraft's fiction. Yet while Lovecraft initially related this profound childhood experience as emotionally overwhelming yet not negative, he had other experiences of overwhelming presence that left him shaken. He describes fears of what he calls "night-gaunts" that haunted him after his father's death, indescribable "things" of his nightmares that so terrified him that he struggled to avoid sleep. Writing to his friend Kleiner, he explained that "I began to have nightmares of the most hideous description, peoples with things which I call 'night-gaunts' - a compound word of my own coinage.... In dreams they were wont to whirl me through space at a sickening rate of speed, the while fretting me and impelling me with their detestable tridents" (Lovecraft to Kleiner 16 November 1916, in Lovecraft 1965a, p. 35). Lovecraft indicated that the night-gaunts continued to plague him into his adulthood, and even inserted them into his stories (Joshi 2001, p. 19). Just as his experience on the railroad bridge represented the positive side of his wonder and awe, the 'mysterium' of the mysterium tremendum, Lovecraft's encounters with the ghostly night-gaunts, who propel him and threaten him, show the overwhelming terror of the 'tremendum,' the overpowering force that simply overcame him. At the same time that the Lovecraft first began to experience these beings, he also began to devour dark fiction, especially enjoying Samuel Coleridge's "Rime of the Ancient Mariner," and the Gustave Dore illustrations within the 1876 edition. Some of the Coleridge's descriptions, such as the slimy legged things from the sea, as well as Dore's haunting images, echo in Lovecraft's later fiction. Lovecraft projected his experiences of awe and wonder through literature and eventually into his own writing.

While Lovecraft had little interest in conventional Protestantism, he took an interest in ancient paganism. While not a Neo-Pagan in any institutional or formal sense, Lovecraft became enamored of Greco-Roman paganism, and began to interpret the "kindred sensations" of imminence, as he called them, through the lens of paganism. Recounting a religious experience that he described later as formative, in fact as the other of the two "most poignant sensations of my existence," and one that has been frequently cited by Lovecraft biographers, he writes that:

When about seven or eight I was a genuine pagan, so intoxicated with the beauty of Greece that I acquired a half-sincere belief in the old gods and Nature-spirits. I have in literal truth 
built altars to Pan, Apollo, Diana, and Athena and have watched for dryads and satyrs in the woods and fields at dusk. Once I firmly thought I beheld some of these sylvan creatures dancing under autumnal oaks; a kind of 'religious experience' as true in its way as the subjective ecstasies of any Christian. If a Christian tell me that he has felt the reality of his Jesus or Jahveh, I can reply that I have seen hoofed Pan and the sisters of the Hespian Phaëthusa.

(Joshi 2010a, p. 3; see also a paraphrase in Lovecraft to Baird, 3 February 1924, Lovecraft 1965a, p. 300)

What is one to make of H.P. Lovecraft's religious background? While he later proclaimed himself a materialist, rejecting supernaturalism, mysticism, and religious belief of all forms, he admits to religious experiences fundamentally shaping his childhood, and when his literary career blossomed, he focused on religious subjects involving deities, cults, and priests. Certainly, his dismissive treatment of religion as quite literally horrible in his stories reveals his personal distaste towards religion, yet its continued presence in his writing indicates that he never quite got religion out of his system.

\section{Lovecraft's (Anti-)Millennialism}

H.P. Lovecraft found himself captivated by an inherently religious sentiment-that of millennialism. While millennialism has multiple meanings and connotations, I follow the approach of Catherine Wessinger, who has characterized millennialism as "the audacious human hope that in the imminent future there will be a transition-either catastrophic or progressive-to a 'collective salvation'" (Wessinger 2011, p. 3). ${ }^{3}$ Yet Lovecraft embodies a peculiar form of millennialism, what I call "anti-millennialism," which entails the reversal of traditional millennialism. For Lovecraft, there is no hope in a collective salvation, but rather expectation that the imminent future would bring a transition to something far worse. From Lovecraft's perspective, and especially in light of his political views during the interwar period, the world faced a future of disunity, social collapse, war, decline, and even destruction. Lovecraft incorporated this anti-millennialist approach into his fiction in stories of religious groups and individuals obsessed with bringing about the end of the world. He combined it with his overwhelming sense of the immanence of something greater in the world, yielding what he called "cosmic dread."

Lovecraft must be understood in reference to his era. Author and Lovecraft commentator Alan Moore explains that, "Lovecraft came of age in an American yet to cohere as a society, much less as an emergent global superpower, and still beset by a wide plethora of terrors and anxieties" (Moore 2014, p. 33). Moore points to Lovecraft's concerns about massive waves of immigration (particularly of non-Anglo-Saxons), opening sexual mores, women's suffrage, the rise of socialism, and new discoveries in science. All this led to cultural transitions that Lovecraft himself abhorred and envisioned as indicative of the end of American civilization. "It is possible to perceive Howard Lovecraft as an almost unbearable sensitive barometer of American dread," argues Moore (2014, p. 13). Other scholars have offered similar readings of Lovecraft's engagement with modernity. Stephen Shapiro and Philip Barnard, whose Pentecostal Modernism accounts for both the emergence of the Pentecostal religious tradition as well as Lovecraft's brand of "weird fiction" as responses to the stew of modernity, argue that Lovecraft's work demonstrates a "critique blocked from articulation" about the failure of institutional systems to account for these changes, with the result that Lovecraft looked backwards into "mythologized Old Ones," much as Pentecostals engaged with formative Christian traditions, or Christian Social Gospelers looked forwards towards social reform (Shapiro and Barnard 2017, p. 144). For Shapiro and Barnard, Lovecraft's well-known racism and nativism represent such an attempt.

3 Wessinger notes that she has distilled the approach of historians Norman Cohn and Yonina Talmon, who offered several models of millennialism, most notably that found in Norman Cohn, The Pursuit of the Millennium: Revolutionary Millenarians and Mystical Anarchists of the Middle Ages, revised edition (New York: Oxford University Press, 1970). 
Lovecraft himself was not shy about his nativism, nor his conservativism. But rather than leading him to political activism, it led him to a nihilism. Lovecraft's anti-immigrant sentiments are well known, as are his social conservatism, anti-Semitism, and racism. "He remained hidebound in the racial theories of the nineteenth century," explains Lovecraft biographer W. Scott Poole, "flirt[ing] with the rising tide of fascism in the last two decades of his life, sometimes mocking Hitler and the Nazis but also frequently defending them and what he thought to be their aims" (Poole 2016a, p. 17). As literary scholars have demonstrated, such positions emerged in his literature. Misogyny (Wisker 2013; Sederholm 2016), racism (Carlin and Allen 2013), and colonialism (Shapiro and Barnard 2017) all appear as tropes in his fiction. Miscegenation particularly concerned Lovecraft, as David Simmons has written, linked to his fears of "non-Western peoples and the racial degeneracy that might arise as a result of miscegenation" (Simmons 2013b, p. 28). Yet his horror at miscegenation, part of his broader nativism, must be read as part of his larger horror at a world run amok. Literary theorist and Lovecraft biographer W. Scott Poole warns that simply discounting the author as a racist (which he was, without a doubt) "ignores Lovecraft's willingness to engage directly with the destructive and horrific possibilities of the twentieth century presaged by World War I and fails to see that his deep pessimism emerged from historical concerns blended with his sense of 'cosmic dread"' (Poole 2016b, p. 38).

Lovecraft, himself, speaking of his philosophical and ideological development in the short intellectual autobiography he penned for friend Edwin Baird, expanding a similar statement from his Confession, claimed that he had moved beyond any school of thought. "I no longer really desire anything but oblivion, and am thus ready to discard any gilded illusion or accept any unpalatable fact with perfect equanimity. I can at last concede willingly that the wishes, hopes, and values of humanity are matters of total indifference to the bland, blind cosmic mechanism" (Lovecraft to Baird, 3 February 1924, in Lovecraft 1965a, p. 303). Lovecraft's racism must therefore be contextualized as one part of an overall anti-millennialist position that looked to the decline of Anglo-Saxon civilization as simply one step towards the inevitable decline of human civilization, a decline that will go unnoticed and unheralded by an indifferent universe. His anti-millennialism, effectively a materialistic variant of religious eschatology, gave meaning to Lovecraft's perception of declension, and both invigorated his racism as well as supported it.

Such nihilism blended with pessimism, leading to the sort of anti-millennialism that envisioned not a collective salvation, but a collective destruction. Lovecraft rooted this philosophy not just in his witness of world events and racist fears of immigration, but also recent scientific developments. Long interested in science, Lovecraft's first publications were not fiction but actually popular science essays, and he remained an avid reader of popular astronomy. Scientific discoveries about the scope and antiquity of the universe and the limited place of humanity within it led Lovecraft to adopt a position that he described as "the futility of all existence" (in Joshi 2010a, p. 5). Biographer S.T. Joshi, in his introduction to the reprinted edition of Lovecraft's "Confession of Unbelief," roots what he calls Lovecraft's cosmicism (or cosmic cynicism as I would label it) in the author's astronomical studies and interest in science (Joshi 2010a, p. vi; see also MacCormack 2016). Cultural change, politics and global affairs, and his own life experiences all combined to lead H.P. Lovecraft to a millennialist position that the human race would face collapse, decline, and an ultimately meaningless end in the imminent future. In keeping with his admission of a constant feeling of immanence or awareness of something greater than himself, his fiction linked this cynical millennial outlook with explicitly supernatural agents imposing themselves into our reality. Pool explains,

Lovecraft, almost alone among the major writers of his era, refused the solace of religion or Communism or fascism or even the certainties of scientific rationalism-in which he did believe but could never find comfort. He saw the irrevocable power of the past offering the possibility of terror as well as solace, and some of his deepest personal and philosophical conflicts arose from the impossibility of staying afloat on what his most famous tail called 'the black seas of infinity.' 
(Poole 2016a, p. 20)

Rather than embrace political or social movements in sympathy with his nativism, deep conservatism, and nihilism, Lovecraft turned to fiction as a means of conveying the sense of social and cultural collapse that he so acutely felt, which combined with his life experiences of facing the madness and death of his parents, his own creeping sense of awe and wonder, and the darkness of his ever-haunting night-gaunts.

Why fiction? Houellebecq argues that Lovecraft embraced fiction because the author despised reality (Houellebecq 2005, p. 30), that his "absolute hatred of the world in general, aggravated by an aversion to the modern world in particular," drove him to write stories about its destruction (Houellebecq 2005, p. 57). Houellebecq's psychoanalysis of Lovecraft can neither be proven nor disproven. However, Lovecraft's own writings as expressed in his Confession and letters indicates that he was drawn to fiction because he wanted to explore themes in which he was invested-materialism and nihilism - through the genres that had most attracted him, namely Victorian horror and speculative fiction. Never a commercially successful writer, Lovecraft wrote to convey his horror at the world, but in a manner that allowed him to emphasize its inevitable decline. Just as he saw social decline in his immediate surroundings, a perspective driven by both his reflections on the Great War and also his racism and nativism, he projected that decline onto a global scale in his fiction. These all culminated in the literary anti-millennialism—of which, "The Call of Cthulhu" is exemplar.

\section{Millennialism in Lovecraft's Narratives}

Turning from the author to the narratives, one finds the presence of the same millennialism (or anti-millennialism, to be technical, since he envisioned no salvation) to which Lovecraft alluded in his letters and essays. Summarizing the collected works, Timothy H. Evans explains that "motivated by an antimodern rejection of industrial capitalism and everything surrounding it-including commercialism, mass culture and immigration-Lovecraft combined an antiquarian interest in folklore and historic material culture with the passions of a preservationist and worries about cultural loss and miscegenation" (Evans 2005, p. 100). Yet writing from his vantagepoint as a folklorist, Evan misses the clear presence of religion in Lovecraft's narratives, as do most other commentators. Lovecraft authored over one hundred stories. ${ }^{4}$ Most emphasized themes of dread of the fearsome supernatural other, threats to individual and collective life, and insanity. The most influential and best known of these short stories fall within what his literary successor August Derleth called the 'Cthulhu mythos,' and nearly all of them detail the human interaction with, and dread of, the ancient deities destined to destroy the Earth. Given the volume of his work, I focus here on three of his most popular stories: "The Call of Cthulhu" (1928), "The Dunwich Horror" (1929), and "The Shadow over Innsmouth" (1936), stories I selected because they are representative of Lovecraft's narrations and themes. I describe each story, draw out the millennial themes in the three, and conclude by linking them back to Lovecraft's biography and cultural context.

\subsection{The Call of Cthulhu}

"The Call of Cthulhu," originally published in the February 1928 issue of the Weird Tales pulp magazine, ${ }^{5}$ gives its name to the mythos within which Lovecraft and his literary constructors set their tales of horror and madness. The story unfolds as a mystery wherein the narrator seeks to piece together clues about unknown religious cults, blasphemous idols, diabolical ritual murders, ancient lore, and the dreams of an insane artist. Religious themes extend throughout, like the tentacles of the titular character. The narrator discovers that a global array of ancient and modern religious cults seeks to awaken the dead god Cthulhu, who sleeps in a sunken city under the sea yet sends out

4 This number incudes unpublished but otherwise documented stories.

5 Nearly all of Lovecraft's short stories are available in myriad forms, both paper and electronic. I make use of one of the many compilations, Lovecraft 1982; See also Klinger 2014. 
haunting dreams that inspire evil and madness. Religious groups worship Cthulhu through ritual and material culture, most notably religious icons of Cthulhu's monstrous form. They seek as their ultimate goal to awaken the god, who will then destroy the world and its inhabitants.

Though the opening sentence of "The Call of Cthulhu" has been frequently cited- "the most merciful thing in the world, I think, is the inability of the human mind to correlate its contents" (Lovecraft 1982, p. 76) - the short story's epigraph actually points more directly to the central conceit. Quoting British occultist and writer of supernatural fiction Algernon Blackwood, Lovecraft opens with a statement on the nature of the divine.

Of such great powers or beings there may be conceivably a survival ... a survival of a hugely remote period when ... consciousness was manifested, perhaps, in shapes and forms long since withdrawn before the tide of advancing humanity ... forms of which poetry and legend alone have caught a flying memory and called them gods, monsters, mythical beings of all sorts and kinds...

(ellipses in original, Lovecraft 1982, p. 76)

Gods, not to mention other mythical beings, represent survivals of ancient glimpses of entities long since expired or otherwise "withdrawn." While today's readers might rightly associate this position with the "ancient alien" school of thought popularized by Swiss ufolist Erich van Däniken, who has insisted that most religions and mythologizes are predicated on ancient contact with extraterrestrials (Hammer and Swartz), Lovecraft here builds on Victorian comparative religion. The short story itself includes a brief mention of James George Frazer's The Golden Bough (1890), though the mention of survivals points also to the work of Edward Burnett Tylor, whose Primitive Culture (1871) helped instigate both comparative religious studies and anthropology. As historiographer Daniel L. Pals shows, the notion of survivals, or "cultural leftovers," was a crucial part of Victorian religious studies, especially for Tylor and Frazer (Pals 2015, pp. 20-21, 30-31). Under this model, one found in surviving superstitions the origins of a multitude of religious beliefs. While Lovecraft does not deny the materialist assumptions in this approach-in fact, he assumes them-he does not harp on the extraterrestrial or biological nature of Cthulhu in this story. Readers are left to imagine Cthulhu as either supernatural or entirely natural, though in fact the ancient god seems to blend aspects of both, given his abilities of psychic projection and action at a distance.

Within the story, beliefs about Cthulhu survived as evidence of the existence of a race of ancient evil beings from beyond the stars, the Old Ones, whose presences remain now only in the forms of myths. Taking a cue from occultists, Lovecraft also imagined such knowledge to persist among secret societies, small religious cults, and among the practitioners of esoteric magic. "The Call of Cthulhu" includes multiple references to theosophy, a nineteenth-century new religion drawing from esoteric as well as Asian religious traditions, that Lovecraft associates with such secret knowledge. In Lovecraft's fiction, theosophical texts, ideas, and groups of actual theosophists all possess some limited knowledge of the existence of Cthulhu and the Old Ones, and the threat they pose to humankind (Lovecraft 1982, pp. $71,81,87-89)^{6}$

Yet while the Anglo-Saxon narrator and some of the sympathetic characters draw on theosophical knowledge, the story revolves around malevolent dark-skinned cultists who not only possess knowledge of Cthulhu, but actually worship this foul being. Lovecraft explicitly refers to these characters as parts of "cults" and "religions," and engaged in "worship," and also describing them as practicing a form of the Haitian Afro-Caribbean religion Voodoo (Lovecraft 1982, pp. 85-88). The clear racial

6 Lovecraft extends this theme of ancient evil extraterrestrial as gods in several later short stories, notably "At the Mountains of Madness" (1931/1936); "The Dreams in the Witch House" (1933); and "The Shadow Out of Time" (1936). In each case, Lovecraft crafts a narrative in which the evil deities worshipped by the corrupt human cultists are in fact extraterrestrial monstrosities. While explicitly materialistic, this does not discount either the millennialism present in the stories, nor the way in which Lovecraft uses religious concepts such as worship, ritual, and texts as part of his fiction. 
hierarchy present in this narrative, with white investigators unraveling the evil secrets of dark-skinned religious zealots, may obscure the fact that Lovecraft did identity these sinister characters with explicitly religious terminology such as idol, fetish, cult, ceremony, worship, and god, albeit language that he associated-in keeping with Tylor and Frazer-with "primitive" religion. From this perspective, it does not matter whether Lovecraft and his Anglo-Saxon narrators recognizes that Cthulhu is "really" a natural extraterrestrial entity rather than supernatural being, since his worshippers consider him truly a god, and worship him as such. (He is, in fact, neither natural not supernatural. Cthulhu is fictional.)

Uniting these disparate references to religion, Lovecraft describes one of the main groups of Cthulhu cultists, a mixed-race gathering in the swamps of Louisiana comprised of "mongrel celebrants," as unambiguously engaged in a form of millennial religious belief and action, hoping to instigate a form of apocalyptic chaos that Wessinger identifies as catastrophic millennialism (Wessinger 2011, p. 5). The characters in Lovecraft's story envision the style of radical disruption associated with catastrophic millennialism but invert the ultimate soteriological act. Whereas catastrophic millennialists generally envision a "imminent, violent destruction of the world as we know it," they also "envisage that God will then act, with or without human assistance, to accomplish a total renovation of the world," as Eugene V. Gallagher explains, building in Wessinger's approach (Gallagher 2011, p. 27). Yet, for the Cthulhu cultists, the "total renovation" represents not a heaven on earth, as one finds in typical Christian catastrophic millennialism and other similar real-life forms of millennialism, but quite literally a hell on earth. Crucially, the cultists believe that this "salvation" will enable them to engage in a sort of ultimate immoral depravity, which effectively represents their soteriological ambition. Lovecraft's character Old Castro, an informant and one of the only sane members of the cult, explains,

That cult would never die till the stars came right again, and the secret priests would take great Cthulhu from His tomb and revive His subjects and resume His rule of earth. The time would be easy to know, for then mankind would have become as the Great Old Ones; free and wild and beyond good and evil, with laws and morals thrown aside and all men shouting and killing and reveling in joy. Then the liberated Old Ones would teach them new ways to shout and kill and revel and enjoy themselves, and all the earth would flame with a holocaust of ecstasy and freedom. Meanwhile the cult, by appropriate rites, must keep alive the memory of those ancient ways and shadow forth the prophecy of their return.

\section{(Lovecraft 1982, p. 88)}

Within the text, Castro offers a catastrophic millennial vision of a holocaust of flame and an orgy of violence. The in-story cult existed so as to keep the hopes for this apocalypse alive, and work towards its enactment. Yet Lovecraft the author managed also to reflect his own anti-millennial sympathies, his nihilistic beliefs that the world was falling into irredeemably disrepair and collapse. Setting "The Call of Cthulhu" in what was for its author the present moment (the fictitious events described occurred in 1927, the year it was written), Lovecraft implied that the time of humankind acting "free and wild and beyond good and evil" had arrived, at least from the perspective of the characters within the story, but also his own. Unlike the cultists of "The Call of Cthulhu," Lovecraft harbored no hope in any teleological end, neither envisioning actual Old Ones teaching new forms of depravity to their worshippers, nor human beings somehow averting of the dawning apocalypse. He simply expected a continuation of "all men shouting and killing and reveling in joy," as his character describes, until humanity destroyed itself. Lovecraft ends his story with the same pessimism. The narrator notes that Cthulhu and his cultists were unsuccessful only in their most recent millennial attempt, but that the cults remain, and Cthulhu waits, sleeping under the sea, and ready to instigate the end of the world. "Who knows the end? What has risen may sink, and what has sunk may rise. Loathsomeness waits and dreams in the deep, and decay spreads over the tottering cities of men. A time will come-but I must not and cannot think!" (Lovecraft 1982, p. 99). 


\subsection{The Dunwich Horror}

Lovecraft's "The Dunwich Horror," published a year later also in Weird Tales, offers a more local yet just as terrifying portrayal of millennial devotion. Set in a fictitious backwater town in rural Massachusetts, the story unfolds as the youngest generation of the Whateleys, a clan of degenerate magicians, comes of age. Wilbur, born of the union between a Whateley woman and the malevolent Old One deity Yog-Sothoth, seeks to fulfill the family's mission of opening a door to an alternative dimension and releasing his Father's wrath into an unsuspecting world. In the words of Lovecraft's Necronomicon, the fictional unholy book that appears throughout his Cthulhu mythos, Yog-Sothoth will "bend the forest and crush the city," replace humanity as earth's masters, and usher in an era of madness and evil (Lovecraft 1982, p. 111). Wilbur, as we discover, is himself a monstrous chimera, and has been secretly feeding his twin brother, an inhuman mass of tentacles, eyes, and mouths that seems to serve some role in the prophecy of the Old One's return. One of Lovecraft's few "happy endings," a trio of academics led by an elderly librarian defeats Wilbur and his twin through sheer determination and good luck. The millennium is averted, but for how long is left unsaid. "You'll never know what the world has escaped," explains the heroic librarian. Yet the future remains unclear. The Necronomicon's prophecy remains, declaring that "They ruled once; They shall soon rule where man rules now. After summer is winter, and after winter summer. They wait patient and potent, for here shall They reign again" (Lovecraft 1982, p. 112).

The Dunwich millennialism is localized but no less calamitous, and like the millennialism of "Call of Cthulhu," it functions as the central theme of the text and the axle around which the narrative turns. Like the earlier story, religious content provides much of the background. But unlike the "Call of Cthulhu," Lovecraft avoids overt religious language. Apart from one reference to "certain forbidden cults" possibly possessing secrets about Yog-Sothoth (Lovecraft 1982, p. 121), and a reference to a (fictitious) historical sermon about the blasphemous devil-worship present in the area (Lovecraft 1982, p. 102) there are almost no explicit religious references. Rather, Lovecraft offers a religious geography and a religious text as context. (The comparison of Wilbur Whateley to Jesus is also left implicit, though hard to miss.)

As classicist Javier Martínez Jiménez has noted (Martínez Jiménez 2018) of Lovecraft's descriptions of the built environment, physical decay represents one of the hallmarks of Lovecraft's spatial portrayals. Literary studies scholar Rebecca Janicker goes further, arguing that "a fictional geography is fundamental to the success of [Lovecraft's] work" (Janicker 2006, p. 54). In the case of "The Dunwich Horror," Lovecraft's treatment of the urban and natural environment functions to portray a central concept within the millennial outlook - that of declension. Such a position entails envisioning a social, cultural, religious, and historical decline that ultimately leads to the millennial upheaval. Varying forms of millennialism imagine differing responses and resolutions, but they are united in approaching decline as a sign of the advent of the millennium.

Lovecraft's Dunwich story invokes spatial declension in this manner. It begins with the memorable description, "When a traveler in north central Massachusetts takes the wrong fork at the junction of the Aylesbury pike just beyond Dean's Corners he comes upon a lonely and curious country. The ground gets higher, and the brier-bordered stone walls press closer and closer against the ruts of the dusty, curving road. The trees of the frequent forest belts seem too large, and the wild weeds, brambles, and grasses attain a luxuriance not often found in settled regions" (Lovecraft 1982, p. 100). Lovecraft continues with descriptions about "malign odour[s]" and "massed mould and decay," and deserted ruined homes (Lovecraft 1982, p. 101). Nature itself has become corrupt, the author describes, with the area surrounding Dunwich far along the "path of retrogression so common in many New-England backwaters" (Lovecraft 1982, p. 101). Summarizing a similar narrative from a different Lovecraft short story, Janicker argues that "the land surrounding this community is—or rather has become-a bad space" (Janicker 2006, p. 58). This describes Dunwich as well.

Against the backdrop of this geographic declension, Lovecraft describes a sort of sacred geography (or more properly, "anti-sacred") wherein the millennial action will commence. Dotting the hilltops 
surrounding Dunwich are a series of megaliths, or standing stones, sometimes also described in the story as stone circles (Lovecraft 1982, pp. 102, 104-5, 108, 130). In particular, the circle atop Sentinel Hill contain an "altarstone" upon which the Whateleys perform obscene sacrifices, blasphemous rituals, and foul magics. Lovecraft leaves it vague whether the Whateley settler ancestors or Native American groups built the stone circles, but the overall role they serve is clear as unholy spaces, haunted inversions of the sort of European megaliths that Lovecraft knew from his readings of British supernatural fiction, places like Stonehenge, Callanish, or Drombeg. At those circles, Wilbur Whateley "shrieked the dreadful name of Yog-Sothoth in the midst of a circle of stones with a great book open in his arms before him" (Lovecraft 1982, p. 105). At the same circles, the trio of heroes also defeat Wilbur's twin brother, the eponymous Dunwich Horror, a massive and monstrous human-god hybrid. "If you men are wise you'll dynamite that altar-stone up there, and pull down all the rings of standing stones on the other hills," warns the hero librarian Armitage at the finale of the story (Lovecraft 1982, p. 133).

Geographic declension offers one avenue by which Lovecraft projects a millennial outlook. Another, as hinted at in the quote's description of Wilbur Whateley's hilltop shrieks, involves the presence of a fictional prophetic book, a sort of unholy Bible, the Necronomicon. As literary scholar Connie Lippert has written, this text has taken on an outsized presence within the Cthulhu mythos, and has been extensively studied by Lovecraft scholars. "The Necronomicon, Lovecraft's fictional grimoire, has been continuously evolved and perpetuated by others and, by now, can be said to have developed a life of its own. It has been borrowed, used and altered to such an extent that, on occasion, certainty of its fictitiousness has become compromised" (Lippert 2012, p. 41). The text appears in multiple Lovecraft stories, including a fictional history of the text itself, and became an integral part of the mythos, with the encouragement of Lovecraft himself, Lippert argues (Lippert 2012, pp. 44-45).

Within "The Dunwich Horror," the Necronomicon appears as a means of establishing a millennial prophecy, explaining the nature of Yog-Sothoth and the other Old Ones, and predicting their return and millennial advent. The section of this fictional text therefore functions as a sort of Cthulhu mythos equivalent of the Christian Book of Revelation, setting the parameters for millennial belief and action. Lovecraft suitably writes the text of the Necronomicon in pseudo-Biblical phrasing reminiscent of the King James translation of the Christian Bible,

The Old Ones were, the Old Ones are, and the Old Ones shall be. Not in the spaces we know, but between them, They walk serene and primal, undimensioned and to us unseen. ... They walk unseen and foul in lonely places where the Words have been spoken and the Rites howled through at their Seasons.... They shall soon rule where man rules now. After summer is winter, and after winter summer. They wait patient and potent, for there shall They reign again.

(Lovecraft 1982, pp. 111-12)

The opening line of this passage may allude to the prologue of the Gospel of John, or possibly also to the cryptic name of God, "I was/am/will be" revealed to Moses at the Burning Bush in Exodus 3:14. Regardless of this literary allusion, the Necronomicon serves the role within the narrative as a Revelation-like text for the Whateley family, who carefully parse and interpret it so as to instigate the millennial vision contained within. The comparison is not perfect, for the Necronomicon also functions as a grimoire or book of spells, and not only as a prophetic or revelatory book. Yet its millennial purpose cannot be denied.

Unlike "The Call of Cthulhu," which ends with a momentary reprieve from the expectations of millennial destruction, "The Dunwich Horror" culminates in what Wessinger calls an avertive millennial model in which the actors successfully prevent the apocalypse. Daniel Wojcik, explaining the Wessinger typology, notes that "unlike in catastrophic millennialism, in avertive apocalyptic thought the destruction of the current world is not entirely predetermined, nor is the world viewed as fatally flawed and unredeemable by human effort" (Wojcik 2011, pp. 66-67). The protagonist within "The Dunwich Horror" represent elements of an avertive millennial plot. Lovecraft himself did not seem 
to adopt this more optimistic perspective of the world, and the overall literary effect of the averted millennium in this short story has received critique as unbelievable or simply falling flat. Genre author and critic Donald R. Burleson rejected it as "suffer[ing] from curious lapses in plot credibility and sound conceptual underpinning" (Burleson 2013, p. 106). That the protagonists defeat an ancient unholy evil "armed with magical incantations and what amounts to a can of bug spray" strains credibility of the story, Burleson notes (Burleson 2013, p. 106). S.T. Joshi makes a similar point, calling the story "painfully inept" (Joshi 2010b, p. 717). I suspect that both Joshi and Burleson, and other critics who find unsatisfying the resolution of "The Dunwich Horror," are implicitly judging the avertive millennial outcome against Lovecraft's own anti-millennial nihilistic worldview. It simply does not make sense for Armitage and his colleagues to have saved the world, when, in a Lovecraftian view, the world is beyond salvation.

\subsection{Shadow over Innsmouth}

"The Shadow over Innsmouth," one of Lovecraft's longer stories and published as a standalone novella, is a coming of age story, at least if "coming of age" entails escaping from a village of mutated amphibious sea people, going insane, and seeking solace in transforming into an immortal human-frog-fish hybrid destined to serve an evil god in an ancient sunken city off the Massachusetts coast. The story's narrator, a young man on college break, detours to the dilapidated seaside town of Innsmouth where he discovers that the townsfolk and in fact the local Protestant houses of worship have come under the sway of the Esoteric Order of Dagon, a church, or "degraded cult" in Lovecraft's words, dedicated to worship of an ancient malevolent sea god (Lovecraft 1982, p. 257). As the unnamed narrator discovers, the townspeople themselves have all slowly transformed into cursed fish-amphibian creatures. The narrator escapes but discovers Innsmouth to be the source of his own ancestry. Briefly considering suicide, instead the narrator succumbs to madness and looks forward to his own transformation and eventual service to the evil god Dagon under the sea.

Like "The Dunwich Horror," unnatural and accursed geography represents the opening salvo of the millennial descriptions of this novella. The same theme of declension in terms of its physical effects predominate. Lovecraft describes "crumbling, worm-eaten" houses, "dead stumps and crumbling foundation walls," "rusted, grass-grown line of the abandoned railway," "dead fish lying about the littered yards" of decrepit houses and inserts into the narrative the protagonist's walking tour of the town, so as to offer additional opportunities for such descriptions (Lovecraft 1982, pp. 246, 255, 256). The author does not merely describe declension through physical decay, he also voices it through his characters. Innsmouth "used to be almost a city—quite a port before the War of 1812-but all gone to pieces in the last hundred years or so," in the words of an unnamed railroad agent advising the narrator against visiting this wretched locale (Lovecraft 1982, p. 248). The protagonist decides to ignore this advice, with Lovecraft describing his thought process as desiring to investigate Innsmouth as a curious case of "civic degeneration" (Lovecraft 1982, p. 251).

Within the novella itself, such declension reflects local social downfall. Yet, for Lovecraft, who populated many of his stories with such a mood of decline, it reveals something broader, an intense feeling of contemporary and impending social collapse. Writing of another Lovecraft short story, "He," but describing a context equally true of the author's description of the fictional Innsmouth, Jay McRoy argues that for Lovecraft, "the social transformations of modern industrial capitalist culture, represented in ' $\mathrm{He}^{\prime}$ by the city's architecture and population, are steps in an inevitable march towards chaos, destruction, and quite possibly, monstrous regeneration" (McRoy 2003, p. 347). McRoy calls this a "chaotic apocalypse," not dissimilar from my own approach. In Lovecraft's actual millennial outlook, he envisioned no recovery from this decline. The world as a whole, America in particular, and New England on the local level, had all witnessed an insurmountable decline, presaging an even further downfall. Not a supernatural apocalyptic outlook, as one more typically finds within millennial thought, Lovecraft's vision focused on human insignificance, and our long-term inconsequentiality. We simply would destroy ourselves if given enough time, and the universe and any conscious entities 
within it did not care. "Shadow over Innsmouth" reflects this position best of the three Lovecraft's stories considered here, since not only does the protagonist encounter the millennial collapse directly, but at the end of the novella after what appears to be a successful escape, he ultimately discovers the futility of his attempts, rooted in his very existence, and he simply yields to his impending fate.

Rebecca Janicker roots Lovecraft's approach within a highly local set of concerns about the decline of New England, especially its shift from a genteel Puritan past to an industrial present marked by a lack of social cohesion. "For Lovecraft, fantastic horror writing is a means of imparting feelings of foreboding, or simple disquiet, about what is going on beneath the surface of their homeland. His works can be shown to echo wider cultural concerns about changes in American society such as urbanisation and social fragmentation, as well as lingering fears about man's place in the wilderness harking from the very birth of the nation. However, these fears can also be narrowed down to reflect more personal concerns about malice and corruption inherent within his native New England" (Janicker 2006, p. 67). Immigration and miscegenation represented the most problematic of such forces within Lovecraft's perspective. His anti-immigrant sympathies led him at times beyond nationalism to flirtations with fascism, and his disgust with the influx of racially ambiguous and dark-skinned immigrants into New England has been well documented (Colebrook 2013). His short-lived marriage to Sonia Greene, a Jewish woman and herself an immigrant, apparently did not change these feelings. Although he expressed these perspectives throughout his fiction, they are especially present in "Shadow over Innsmouth," as articulated through the protagonist's frequently-voiced disgust at the "queer kinds of people" within the town, which he believes are the result of "race mixing" between New Englanders and the denizens of "some heathen port" (Lovecraft 1982, pp. 249-50)

Lovecraft reserved the most abject decay and millennial foreboding of Innsmouth for his descriptions of the town's religion. The unnamed narrator's encounter with a "ghoulish, decapitated steeple of an ancient church" during his walking tour of the town extends the physical declension theme into the religious spaces of Innsmouth (Lovecraft 1982, p. 262), but the true depths to which religion has sunk are revealed only when the protagonist catches glimpses of the Esoteric Order of Dagon, the religious establishment of the town and the source of its apocalyptic decline. Dedicated to the worship of the eponymous malevolent Deep One deity (Lovecraft is vague about the relation of the Deep Ones to the Old Ones, calling Yog-Sothoth and Cthulhu "cousins") the Esoteric Order represents within the story the primary force of moral decay. Tellingly, it emerged from an unholy mixing between foreign "heathen" religiosity and the native-born sea captain Obed Marsh, who not only introduced worship of the Deep Ones to the town, but also mated with them, initiating a lineage of hybrid offspring now overrunning the town. Lovecraft's own fears of immigration and racial miscegenation, and their effects on American society, could not be clearer in this millennial vision.

Lovecraft's own agnosticism and lack of interest in formal religious institutions (nor his materialism and anti-supernaturalism) did not prevent him from utilizing the theme of religious institutional decline within the story. The horror of Christian decline he roots in the same sort of mixing that resulted in the racial decline of the town's inhabitants. In a single paragraph, Lovecraft variously describes the Esoteric Order and its influences on the local churches as "a peculiar secret cult which has gained force there and engulfed all the orthodox churches," but also "a debased, quasi-pagan thing imported from the East a century before" (Lovecraft 1982, p. 253). The Esoteric Order's religious practices, Lovecraft describes, demonstrate a variety of nefarious foreign influences, including "peculiar vestments," headdresses, jewelry reminiscent of distant lands, and foreign languages. Rather than finding such exoticism appealing, the narrator initially (before his ultimate downfall in the final pages) reacts with revulsion. Worst was the sounds of their human-amphibious bodies, slowly transforming into something resembling their Deep One lineage. The sounds of the movement and especially their speech repulsed the protagonist. "Their voices were disgusting. It was awful to hear them chanting in their churches all night, and especially during their main festivals or revivals" (Lovecraft 1982, p. 259).

If readers stop a few pages from the end of "Shadow over Innsmouth," they might conceivably imagine Lovecraft's story to fit within the avertive millennial outlook. The unnamed narrator escapes 
the dreadful town, reports its condition to the local authorities, who dynamite the Esoteric Order of Dagon's buildings, incarcerate its leaders, and apparently put an end to its activities. This parallels "The Dunwich Horror," and Armitage's suggestion that they simply blow up the standing stones. Yet the protagonist does not truly escape Innsmouth, nor is the Esoteric Order really gone. The final pages of the novella indicate that the protagonist himself becomes an antagonist, at least from the perspective of social order. Discovering himself to also be the spawn of Deep One miscegenation, he plans a jailbreak to release a cousin from an insane asylum, hoping to together join their kinfolk (Lovecraft 1982, p. 295). The narrator ultimately succumbs to the same sort of nihilistic anti-millennialism that describes Lovecraft himself, "The Deep Ones could never be destroyed ... they would rise again.... It would be a city greater than Innsmouth next time. They had planned to spread, and had brought up that which would help them, but now they must wait once more" (Lovecraft 1982, p. 295). The millennial endtimes were not avoided, only postponed, just as Lovecraft envisioned no solution to the state of humanity as he gazed into the future in the decade after the Great War. The story ends with an almost religious refrain, as the narrator waxes on his dreams for the future, "We shall swim out to that brooding reef in the sea and dive down through black abysses to Cyclopean and many-columned Y'ha-nthlei, and in that lair of the Deep Ones we shall dwell amidst wonder and glory for ever" (Lovecraft 1982, p. 295). One almost imagines an "Amen."

\section{Conclusions}

Tracy Bealer has argued that "Shadow over Innsmouth" reveals Lovecraft's intense horror in the face of "historical modernity" (Bealer 2011, p. 43). The story pivots around the racialized other, and modernist anxieties about race. Bealer's argument holds for Lovecraft's other stories as well, not only anxieties about race, but a broader angst in the face of modernity. Decay, collapse, and destruction are central motifs of all three stories: global in the case of Call of Cthulhu, local for Dunwich, and local/individual for Innsmouth, whose narrator moves from hero to impending villain. Religious corruption and decay serve as narrative means of expressing this motif. "Call of Cthulhu" centers on evil cults and icons, Dunwich on evil rituals and the unholy text of the Necronomicon, and Innsmouth on corrupted churches. Lovecraft's description of the state of religion in Innsmouth captures this sense of decay, describing the Innsmouth churches under Dagon's influence:

Those churches were very odd-all violently disavowed by their respective denominations elsewhere, and apparently using the queerest kind of ceremonials and clerical vestments. Their creeds were heterodox and mysterious, involving hints of certain marvelous transformations leading to bodily immortality—of a sort—on this earth.

(p. 259)

Fears of religious declension of course harkens back to the Puritan era, but Lovecraft uses religious, social, and physical decay as evidence of a slide towards a violent and destructive end of the world. The Order of Dagon wishes to unleash an evil deity on the planet, just as Wilbur Whateley and his family seek to open the gate to an outer dimension to usher in the Old Ones as the new rulers of Earth. Lovecraft describes not only the home of the Whateleys but even the town and land around them as corrupt and sinister, filled with "gorges and ravines of problematical depth," and a town of "rotting gambrel roofs" (Lovecraft 1982, pp. 100-1). The Cthulhu-worshipping cults Lovecraft describes as "degenerate," and engaged in the foulest of activities. "Animal fury and orgiastic licence here whipped themselves to daemoniac heights by howls and squawking ecstasies that tore and reverberated through those nighted woods like pestilential tempests from the gulfs of hell," he writes (Lovecraft 1982, p. 85).

For many millennialist believers, such declension can only lead to the advent of the millennium. Christian Dispensationalists-a millennial perspective often found among Evangelicals-look to social and religious decline before the rapture and the unfolding the millennial timetable. Some millennially-oriented Jews in both medieval and modern times have looked to religious decline as preceding the coming of the messiah. Buddhist millennialists envision the decline of the dharma 
before the advent of the Buddha-to-come, Maitreya. ${ }^{7}$ Lovecraft's fiction embodies the same millennial focus on declension, yet rather that hold out hope in the arrival of Christ, a Davidic King, or Maitreya, his characters come to realize that inevitably the Old Ones will return and wreak havoc if not complete destruction on the Earth. Cthulhu is clearly not Jesus, Yog-Sothoth not the messiah, but they serve the same functional role in the millennial story. Such deities represent the end of the world in its current form and phase, and the advent of a new age.

Lovecraft himself was a materialist and a cynic, and neither I nor his biographers claim that he actually believed in the reality of the Old Ones or any sort of prophesied end of the world at their hands (or tentacles). Yet his fiction encapsulates the sort of intensive awareness of something greater than himself that he felt as a child overlooking the city of Providence, and the same sort of dread he felt at night when visited by his night-gaunts. A privileged white man tracing his ancestry to New England Puritans who nevertheless felt ostracized and alienated by a modern society, and who in fact lived most of his life impoverished and alone, Lovecraft offered a particular vantage point from which to perceive social change, or what he considered the decline and destruction of Western civilization. His stories capture his sense of dread and overwhelming immanence, and expectations of social decline, collapse, and failure. A conservative nativist who envisioned immigration, racial diversity, and cultural change as indicative of the end of Anglo-American civilization, Lovecraft authored fiction wherein miscegenation, social collapse, and dark-skinned others represented the advent of the end of the world. Casting these changes into the context of global millennialism, Lovecraft effectively harnessed the power of religious concepts and language to project a nihilist materialist philosophy through his fiction. Lovecraft, like his characters, expected and perhaps even hoped for the end of the world. We may not particularly like Lovecraft as a person, but there is no doubt that his fiction has been successful, and that his works embody a millennialist expectation that reflects early twentieth-century society, contemporary historical developments, and the changing cultural milieu in which he lived.

Funding: This research received no external funding.

Acknowledgments: This article is based on an oral presentation at the 2015 annual meeting of the American Academy of Religion. I am grateful to the organizers of that panel and the audience members for their questions and suggestions. My former research assistant Michael Janeček greatly assisted with assembling materials, and insightful conversations, and I gratefully acknowledge his assistance as well. Finally, I thank the anonymous reviewers for their comments on the earlier version of this article, and direction towards several important sources.

Conflicts of Interest: The author declares no conflicts of interest.

\section{References}

Bealer, Tracy. 2011. 'The Innsmouth Look': H.P. Lovecraft's Ambivalent Modernism. Journal of Philosophy 6: $43-49$. [CrossRef]

Bolton, K. R. 2011. The Influence of H.P. Lovecraft on Occultism. Irish Journal of Gothic and Horror Studies 9: 2-21. Burleson, Donald R. 2013. On the Dunwich Horror. New Critical Essays. Edited by H.P. Lovecraft. New York: Palgrave Macmillan, pp. 105-17.

Camp, L. Sprague de. 1975. Lovecraft: A Biography. Garden City: Doubleday and Company.

Card, Jeb J. 2019. Witches and Aliens: How an Archaeologist Inspired Two New Religious Movements. Nova Religio 22: 44-59. [CrossRef]

Carlin, Gerry, and Nicola Allen. 2013. Slime and Western Man: H.P. Lovecraft in the Time of Modernism. New Critical Essays. Edited by H.P. Lovecraft. New York: Palgrave Macmillan, pp. 73-90.

Caterine, Darryl V. 2014. Heirs through Fear: Indian Curses, Accursed Indian Lands, and White Christian Sovereignty in America. Nova Religio 18: 37-57. [CrossRef]

Colavito, Jason. 2005. The Cult of Alien Gods: H.P. Lovecraft and Extraterrestrial Pop Culture, Amherst: Prometheus Books.

7 For details on these millennial models, see the relevant chapters in Wessinger 2011. 
Colebrook, Martyn. 2013. 'Comrades in Tentacles': H.P Lovecraft and China Miéville. New Critical Essays. Edited by H.P. Lovecraft. New York: Palgrave Macmillan, pp. 209-26.

Davis, Erik. 2014. H.P. Lovecraft. In The Occult World. Edited by Christopher Partridge. London: Routledge, pp. 492-98.

Engle, John. 2014. Cults of Lovecraft: The Impact of H.P. Lovecraft's Fiction on Contemporary Occult Practices. Mythlore 33: 85-98.

Evans, Timothy H. 2005. A Last Defense against the Dark: Folklore, Horror, and the Uses of Tradition in the Works of H.P. Lovecraft. Journal of Folklore Research 42: 99-135. [CrossRef]

Gallagher, Eugene V. 2011. Catastrophic Millennialism. In The Oxford Handbook of Millennialism. Edited by Catherine Wessinger. New York: Oxford University Press, pp. 27-43.

Hammer, Olav, and Karen Swartz. Forthcoming. Ancient Aliens. In Handbook of UFO Religions. Edited by Benjamin E. Zeller. Leiden: Brill.

Hanegraaff, Wouter J. 2007. Fiction in the Desert of the Real: Lovecraft's Cthulhu Mythos. Aries 7: 85-109. [CrossRef]

Hantke, Steffen. 2013. From the Library of American to the Mountains of Madness: Recent Discourse on H.P. Lovecraft. New Critical Essays. Edited by H.P. Lovecraft. New York: Palgrave Macmillan, pp. 135-56.

Harman, Graham. 2012. Weird Realism: Lovecraft and Philosophy. London: Zero Books.

Houellebecq, Michel. 2005. H.P. Lovecraft: Against the World, Against Life. Translated by Dorna Khazeni. San Francisco: Contre le monde, contre la vie, Originally published as H.P. Lovecraft: Contre le monde, contre la vie.

Janicker, Rebecca. 2006. New England Narratives: Space and Place in the Fiction of H.P. Lovecraft. Extrapolation 48: 56-72. [CrossRef]

Jarocha-Ernst, Chris. 1999. A Cthulhu Mythos Bibliography \& Concordance. Seattle: Armitage House.

Joshi, S.T. 2001. A Dreamer and Visionary: H.P. Lovecraft in His Time. Liverpool: Liverpool University Press.

Joshi, S.T., ed. 2010a. Against Religion: The Atheist Writings of H.P. Lovecraft. New York: Sporting Gentlemen Press. Joshi, S.T. 2010b. I am Providence: The Life and Times of H.P. Lovecraft. 2 vols. New York: Hippocampus Press.

Klinger, Leslie S., ed. 2014. The New Annotated H.P. Lovecraft. New York: W.W. Norton \& Company.

Lippert, Conny. 2012. Lovecraft's Grimoires: Intertextuality and the Necronomicon. Working with English: Medieval and Modern Language, Literature and Drama 8. Gothic Histories: 41-50. Available online: https: //www.academia.edu/5371242/Lovecrafts_Grimoires_Intertextuality_and_the_Necronomicon (accessed on 29 December 2019).

Lovecraft, H.P. 1965a. Selected Letters: 1911-1924. 1 vol. Edited by August Derleth and Donald Wandrei. Sauk City: Arkham House.

Lovecraft, H.P. 1965b. Selected Letters: 1929-1931. 3 vols. Edited by August Derleth and Donald Wandrei. Sauk City: Arkham House.

Lovecraft, H.P. 1982. The Best of H.P. Lovecraft: Bloodcurdling Tales of Horror and the Macabre. Republished Material. New York: Del Rey.

MacCormack, Patricia. 2016. Lovecraft's Cosmic Ethics. In The Age of Lovecraft. Edited by Carl H. Sederholm and Jeffrey Andrew Weinstock. Minneapolis: University of Minnesota Press, pp. 199-214.

Mackley, J.S. 2013. The Shadow over Derleth: Disseminating the Mythos in the Trail of Cthulhu. New Critical Essays. Edited by H.P. Lovecraft. New York: Palgrave Macmillan, pp. 119-34.

Martínez Jiménez, Javier. 2018. The Impact of the Eldritch City: Classical and Alien Urbanism in H.P. Lovecraft's Mythos. Foundation 47: 29-42.

McRoy, Jay. 2003. There Goes the Neighborhood: Chaotic Apocalypse and Monstrous Genesis in H.P. Lovecraft's 'The Street,' 'The Horror at Red Hook,' and 'He.'. Journal of the Fantastic in the Arts 13: 335-51.

Moore, Alan. 2014. Introduction to the New Annotated H.P. Lovecraft. Edited by Leslie S. Klinger. New York: W.W. Norton \& Company.

Moreland, Sean, ed. 2018a. New Directions in Supernatural Horror Literature: The Critical Influence of H.P. Lovecraft. Lovecraft. Cham: Palgrave Macmillan.

Moreland, Sean. 2018b. The Birth of Cosmic Horror from the S(ub)lime of Lucretius. In New Directions in Supernatural Horror Literature: The Critical Influence of H.P. Lovecraft. Edited by Sean Moreland. Cham: Palgrave Macmillan, pp. 13-42.

Nahim, Paul J. 2014. Holy Sci Fi! Where Science Fiction and Religion Intersect. Berlin: Springer. 
Otto, Rudolf. 1917. Das Heilige: Über das Irrationale in der Idee des Göttlichen und sein Verhältnis zum Rationalen. Munich: Verlag.

Pals, Daniel L. 2015. Nine Theories of Religion, 3rd ed.Oxford University Press: Oxford.

Poole, W. Scott. 2016a. In the Mountains of Madness: The Life and Extraordinary Afterlife of H.P. Lovecraft. Berkeley: Soft Skull Press.

Poole, W. Scott. 2016b. Historicizing Lovecraft: The Great War and America's Cosmic Dread. Interdisciplinary Humanities 33: 36-52.

Sederholm, Carl H. 2016. H.P Lovecraft's Reluctant Sexuality: Abjection and the Monstrous Feminine in 'The Dunwich Horror. In The Age of Lovecraft. Edited by Carl H. Sederholm and Jeffrey Andrew Weinstock. Minneapolis: University of Minnesota Press, pp. 133-48.

Sederholm, Carl H., and Jeffrey Andrew Weinstock, eds. 2016. The Age of Lovecraft. Minneapolis: University of Minnesota Press.

Shapiro, Stephen, and Philip Barnard. 2017. Pentecostal Modernism: Lovecraft, Los Angeles, and World-Systems Culture. New York: Bloomsbury Academic.

Simmons, David, ed. 2013a. New Critical Essays on H.P. Lovecraft. New York: Palgrave Macmillan.

Simmons, David. 2013b. 'A Certain Resemblance': Abject Hybridity in H.P. Lovecraft's Short Fiction. New Critical Essays. Edited by H.P. Lovecraft. New York: Palgrave Macmillan, pp. 13-30.

Wessinger, Catherine, ed. 2011. The Oxford Handbook of Millennialism. New York: Oxford University Press.

Wisker, Gina. 2013. 'Spawn of the Pit': Lavinia, Marceline, Medusa, and All Things Fouls: H.P. Lovecraft's Liminal Women. New Critical Essays. Edited by H.P. Lovecraft. New York: Palgrave Macmillan, pp. 31-54.

Wojcik, Daniel. 2011. Avertive Apocalypticism. In The Oxford Handbook of Millennialism. Edited by Catherine Wessinger. New York: Oxford University Press, pp. 6-88.

(C) 2019 by the author. Licensee MDPI, Basel, Switzerland. This article is an open access article distributed under the terms and conditions of the Creative Commons Attribution (CC BY) license (http://creativecommons.org/licenses/by/4.0/). 